Статья/Original article

УДК 94(47)

DOI 10.18413/2312-3044-2021-8-2-155-178

\title{
Bessarabian Nobility: Composition and Land Tenure
}

\author{
V. V. Morozan \\ St. Petersburg State University \\ 7-9, Universitetskaya nab., St. Petersburg, 199034, Russia \\ E-mail: v.morozan@spbu.ru
}

\begin{abstract}
This article deals with the evolution of the numerical strength of the Bessarabian nobility and its land ownership. The work provides statistical information on the numbers of both the entire nobility of Bessarabia and for individual counties in different periods of time, starting from 1821. The author also analyzes the state of affairs with the land ownership of the upper class of Bessarabia in the nineteenth through early twentieth centuries. Information on the total amount of land ownership is provided, and the average indicators of ownership for individual years are determined. Problems with the arrears of the nobility to land banks, in particular to the State Noble Land Bank, are noted. Also, the article deals with the problems of land losses of the nobles as a result of the inability of a part of the Bessarabian elite to effectively run their households.
\end{abstract}

Keywords: nobles, Bessarabia, Russian Empire, nineteenth century, early twentieth century, land tenure, credit

Copyright: (C) 2021. Morozan V. This is an open-access publication distributed under the terms of the Creative Commons Attribution License, which permits unrestricted use, distribution, and reproduction in any medium, provided the original authors and source, the Tractus Aevorum journal, are credited.

The fate of the noble society of Bessarabia is one of the shortest in the history of the Russian Empire. Having emerged in the first quarter of the nineteenth century, it did not last even a century. It is noteworthy that this privileged social group was formed by the efforts of the tsarist authorities from the people who had a direct or indirect relationship to the bureaucracy of the Moldavian principality as part of the Ottoman Empire. The right to nobility was given by ranks acquired in the past or by direct 
kinship with class officials, fathers and grandfathers. In other words, the Russian tradition of acquiring higher estate rights was applied to the nobility of Bessarabia. On the one hand, these rules equalized the noblemen of the region with the native nobles of Russia, on the other hand, they put certain obstacles in front of the applicants for the class title. Each pretender to the nobility had to confirm their rights with documents, therefore, it was necessary to acquire the corresponding papers.

However, at the initial stage of Bessarabia's entry into Russia, the requirements for the former boyar ranks were not very strict. The tsarist authorities, who needed the support of the local elite, did not strive for a tough selection of future nobles. From 1812 to 1821, there was a very formal attitude of the imperial administration towards those persons who showed themselves off as Moldovan boyars. With an acute shortage of personnel for the local administration in those years, the tsarist government was ready to accept all persons loyal to Russia into service once they considered themselves noble. By the beginning of the third decade, when the process of drawing up the basic legal norms for managing the new territory was completed and administrative structures were created, a more rigid attitude towards the composition of the local elite arose. The issue of recruiting the Bessarabian administration had partly been resolved by that time via attracting officials from the neighboring parts of Russia, especially from the Podolsk, Volyn and Kherson provinces. Thus, it took the tsarist authorities almost a decade to create conditions for the formation of a full-fledged noble society in Bessarabia.

Thus, on February 10, 1821, the Commission for the consideration of documents on the estate of former Moldavian boyars began to work. Unlike previous similar establishments, the Commission of 1821 stood out for a more rigorous and qualified examination of the documents submitted. It was headed by the acting plenipotentiary governor of Bessarabia I.N. Inzov. Members of the Comission were 13 boyars well-known in Bessarabia headed by the local leader of the nobility Dmitry Ryshkan. On February 17, 1821, Lieutenant General Inzov signed the corresponding instruction, which indicated documents acceptable for the commission to prove the noble origin. It also included extracts from Russian legislation, explaining on what grounds the applicants were ranked as noble. ${ }^{1}$

The Commission on the nobility finished its work on December 10, 1821. The result of its work was a list of 189 names with a special definition of the right to nobility passed for each. Note that only 127 of them received the right to participate in the elections of deputies to the noble assembly. Of this number, 66 people could elect their deputies in

${ }^{1}$ I.N. Inzov - I.A. Kapodistria. March 6, 1821. Russian State Historical Archives (hereinafter RSHA). F. 1308. L. 1. Vol. 29, sheet 4. 
Orgeyev Uyezd, 37 in Iasi, 19 in Khotin, 4 in Bender and 1 in Izmail. ${ }^{2}$ The rest of the Bessarabian nobles, who did not own the required amount of land or did not receive their hereditary portions, were left without the right to elect deputies.

Having determined the circle of persons for participation in the elections, the tsarist authorities also appointed the date of the noble meeting, which was to be held on December 29, 1821. However, the meeting actually opened only on January 3,1822 . Thus, at the beginning of 1822, a local noble society was formed in Bessarabia, whose members had equal rights with the Russian nobles, with the exception of the right to own serfs within the region. However, they could buy and own inhabited estates elsewhere in Russia. On March 11, 1822, General I.N. Inzov instructed the regional leader of the nobility I.M. Sturdze to submit all the original decisions of the Commission of 1821 and an alphabetical list of nobles to the Bessarabian Supreme Council for compiling, in accordance with the Charter of establishing the region, a genealogical book. ${ }^{3}$ Work on it went unhurriedly, of which I.N. Inzov reported in May 1823 to the Minister of Internal Affairs, Count V.P. Kochubei. ${ }^{4}$ For this reason, the compilation of the genealogical book was only completed in August 1823.

The register of 189 noble families was revised in 1824 by the Supreme Council of the Bessarabian region, which retained only 102 names in it. The reason for the revision was the separate registration by the Commission of 1821 of the younger noble families rather than assigning them to the families of their fathers. After the audit, the Supreme Council began editing the genealogy of the book. As a result of this work, which was completed only by 1827,61 families entered the first part of the noble genealogy book, 12 families entered the second part, 7 families entered the third part, one family entered the fifth part of the book and 19 names entered the sixth part. ${ }^{5}$ In this regard, it is important to determine the number of the region's nobles at the specified time (Table 1).

Data in Table 1 show that the number of nobles in Bessarabia was small. There were only 353 hereditary nobles in 1828 , or about 0.1 percent of the total population of the region. About $1 / 3$ of them could take part in the noble elections. Note that this category of full-fledged nobles increased extremely slowly in subsequent years. So, in 1835 the number of such persons slightly exceeded 200 people. More detailed information on the distribution of the nobility by region is given in Table 2. From the above information, it can be seen that only 210 persons had the right to vote, which they obtained through the possession of 300 or more dessiatines

\footnotetext{
${ }^{2}$ I.N. Inzov - I.A. Kapodistria. February 7, 1821. Ibid, sheet 14.

${ }^{3}$ A short note from the case on the formation of a noble genealogy book, compiled according to the definitions of a special commission that existed in Bessarabia in 1821 to consider evidence for a noble title. RSHA. F. 1151. L. 3 (1844). Vol. 231, sheet 2.

${ }^{4}$ I.N. Inzov - V. P. Kochubei. May 9, 1823. RSHA. F. 1308. L. 1.Vol. 29, sheet 27.

5 I.N. Inzov - I.A. Kapodistria. February 7, 1821. RSHA. F. 1308. L. 1.Vol. 29, sheet 14.
} 
(slightly over 800 acres) of land. That stands for less than $30 \%$ of the total number of all nobles living in the region (Table 2).

Note that in the following decades, the growth in numbers of the nobility did not change. Thus, in 1848,2262 noblemen lived in Bessarabia. However, only 658 of them were included in the local genealogy book. The heads of the families of the upper class were 513 persons. A significant part of the nobles who lived in 1848 were numbered among other parts of the empire. In particular, 438 people were included mainly in the genealogical books of neighboring provinces. The remaining 1166 persons were not approved by the Senate in their rank. The region was also inhabited by 984 people who were personal nobles. Of these, 622 persons were on public service. 6 Thus, a little more than 200 people had a full right to participate in the life of the local noble society, with the right to vote in elections.

It is noteworthy that the distribution of the nobility in the province was extremely uneven. So, among the persons included in the genealogy book in Bendery Uyezd there were only 4 heads of noble families raising four sons, and 2 bachelors. Another 11 people who lived in the same district were taken out of the books of other provinces. They had 5 sons who were not included in the genealogical books. In addition, 21 people claimed to be nobility, but they have not yet been entered in the genealogy book. They had 8 sons. Thus, there were 55 people in the district who were related to the hereditary nobility (for more details, see table 3). Another 35 people were personal nobles, of whom 17 were in the civil service ${ }^{7}$ (Table $3)$.

Considering the further increase in number of the Bessarabian nobles, we point out that by 1850 the number of full-fledged nobles still slightly exceeded the mark of 200 people. ${ }^{8}$ Altogether, 2691 noblemen lived in the region in 1849,92699 in 1850,103157 in $1852,{ }^{11} 3122$ in 1853.12 There were 3050, 2718, 4343 and 2854 personal nobles, respectively ${ }^{13}$ (more details are given in table 4). Obviously, most of the personal nobles acquired this title due to their merits after the annexation of Bessarabia to Russia, or were among the newcomers to the region.

\footnotetext{
6 Statement on the number of hereditary and personal nobles living in the Bessarabian region. NARM: F. 88. L. 1. Vol. 1262, sheets 258-259.

7 Ibid, sheets $10-11$.

${ }^{8}$ Report on the state of the Bessarabian region of 1850 . RSHA. F. 1281. L. 5. Vol. 54, sheet 105.

9 Report on the state of the Bessarabian region of 1849. Ibid. Vol. 58, sheet 46.

10 Report on the state of the Bessarabian region of 1850. Ibid. Vol. 54, sheet 105.

${ }^{11}$ Report on the state of the Bessarabian region of 1852. Ibid. Vol. 86, sheet 95.

12 Ibid. Vol. 87, sheet 98 .

${ }^{13}$ Report on the state of the Bessarabian region of 1849 . Ibid. Vol. 58 , sheet 46; Report on the state of the Bessarabian region of 1850. RSHA. F. 1281. L. 5. Vol. 54, sheet 105; Report on the state of the Bessarabian region of 1852. Ibid. Vol. 86, sheet 95; Report on the state of the Bessarabian region of 1852. Ibid. Vol. 87, sheet 98.
} 
Only 228 men and 194 women with the rank of personal noblemen belonged to the category of the so-called warrior women, who previously held minor official positions under the Moldovan rulers. In 1853, there were 3122 hereditary nobles in the region of both sexes, and there were 2854 personal nobles. ${ }^{14}$ In 1854 there were 3376 and 2849 such persons, respectively, ${ }^{15}$ and in 1856 there were 3795 hereditary and 4864 personal nobles ${ }^{16}$ (Table 4).

Of the 200 people with the right to vote mentioned above, up to fifty noblemen or a little more did not take part in regular noble meetings. Most often, the reasons for refusing to participate in the election campaign were unwillingness to bear the costs of staying in Chisinau or weather conditions that prevented travel to the province capital. Often, this category of passive nobles transferred their voting rights to others. For this reason, some of the participants in the meetings of the nobility voted not on their own behalf only. This category also includes those who acted at these events as confidants of noblewomen or a certain circle of small-land nobles. In particular, in 1857, 102 electors had 159 votes, that is, 57 people had 2 votes. In 1860, 146 people were present at the elections of the regional leader of the nobility, ${ }^{17}$ who could vote for 190 people, or 44 voters had 2 votes. ${ }^{18}$

Interesting data for 1861 is given in the notes by the Bessarabian Regional Statistical Committee, which are shown in Table 5. In total, according to these data, 9193 noblemen lived in the region, of which 4719 were men. It is noteworthy that out of the total number of people of the upper class, 4694 people lived in the cities of the region. A particularly large number of nobles lived in Chisinau, 2901 people. ${ }^{19}$ Obviously, the bulk of the nobles living in the central city of Bessarabia belonged to the number of officials who stayed in the region only for the duration of their service. There were also many unserviceable nobles in the region who had a very distant relation to the local elite, like retired officers who succeeded during their short service marry Bessarabian noblewomen. They were associated with the region only due to the land holdings of their wives and, as a rule, did not plan to permanently live in the region. In a word, there were a lot of people temporarily staying in Bessarabia. Comparing the nubmer of the Bessarabian nobility of the third quarter of the nineteenth century with the numbers of such people in other

\footnotetext{
${ }^{14}$ Report on the state of the Bessarabian region of 1853 Ibid. L. 5 (1854). Vol. 78, sheet 98 rev.

${ }^{15}$ Report on the state of the Bessarabian region of 1854 Ibid. L. 6 (1855). Vol. 76, sheet 102.

16 Zashchuk, 1862. Vol 1,188.

17 M.L. Fanton-de-Verrion to S.S. Lansky. April 13, 1860. RSHA. F. 1284. L. 48 (1860). Vol. 67, sheet 10 rev.

18 List of hereditary nobility of the Bessarabian region, appointed to run for the title of regional leader of the nobility of February 8, 1860. Ibid. Vol. 22, sheet 12.

19 Notes of the Bessarabian Regional Statistical Committee. Cisinau, 1864.Vol. 1.P. 31.
} 
provinces of Russia shows a pronounced lag. Thus, in 1858, only hereditary nobles in the Ryazan province made up 3851 people. ${ }^{20}$ In 1861 , 11617 hereditary and personal nobles lived in Voronezh province, 15645 people lived in Kursk province. ${ }^{21}$ In Kazan province in 1870 there were 6226 such persons, in Penza province there were 6926, in Simbirsk province 5866 people.22 When comparing the number of Bessarabian nobles with those in the western provinces of the country, this difference will be even more significant (Table 5).

Studying the composition of the Bessarabian noblity for different years, we note that in the middle of the nineteenth century, most of them showed little interest in the life of their class. One of the problems of the low involvement of the nobles in the life of the class was that there were many impoverished nobles in the region. So, out of 1129 private estates in Bessarabia, only 672 belonged to persons of "noble rank". ${ }^{23}$ At the same time, large landowners owned several estates. A certain amount of the landowners were not part of the local nobility and did not actually live in the region. The ethno-confessional composition of the Bessarabian nobility was also extremely variegated. The share of non-indigenous nobility in the north and south of Bessarabia was especially significant. According to the observations of one of the travelers who visited the region in the 1860s, the estates of ethnic Moldovans in the Khotin Uyezd were greatly diluted by Russian, Greek and Jewish landholdings. ${ }^{24}$

Among the total mass of the Bessarabian noblemen, there was a large proportion of land-poor or landless families. So, in the early 1850 s, there were 40 such families in the region, approved by the Heraldry Department in the highest class rank. Another 186 such families were awaiting the decision of the Senate on their estate status. The noblemen of this group possessed several dozen acres of land or were completely landless, acting as tenants for wealthier landowners. Among the tenants there were a considerable number of newcomers who lived in the region, mainly to do their duty. Some of them, having served in the region for a decade, have not been able to acquire their own land holdings. Others did not set themselves such a goal. Lack of real estate for such persons in the Bessarabian region did not contribute to their desire to join the Bessarabian nobility. That is why the number of nobles included in the genealogy book was relatively small. For example, for the period from 1824 to 1871 , only 190 families were recognized by the Bessarabian noble deputy assembly and then approved by Senate in the noble rank. These

\footnotetext{
20 Materials for geography and statistics of Russia, collected by officers of the General Staff. Ryazan province. Comp. M. Baranovich. Saint Petersburg, 1860, p. 138

${ }^{21}$ Shapovalov 2014, $50-51$.

22 Fedoseeva 2014, 199.

${ }^{23}$ Report of the Bessarabian Governor of 1869. RSHA. F. 1281. L. 7 (1870). Vol. 72 , sheet 6.

${ }^{24}$ Romania: Tales of Bessarabia, Bukovina, Moldavia and Wallachia: with a Historical Sketch. $1868,12$.
} 
families had 697 men and 149 women, or a total of 846 people. ${ }^{25}$ However, it should be noted that the Senate received significantly more cases from the noble assembly, which more easily ranked many interested persons among its class. So, in the period from 1821 to 1854, 431 heads of families, which consisted of 2198 people, tried to acquire the nobility. However, from 1812 to 1854 , the Senate recognized only 214 families, which consisted of 445 people, as noble families. Another 217 families were either not approved by the Herald, the Temporary Heraldry Presence or the Heraldry Department, depending on the time of the case, or were still awaiting Senate decrees. These 217 families included 1753 people, of which 410 people were denied the right to nobility by the Senate. ${ }^{26}$ However, despite numerous difficulties in submitting documents for the nobility, the ranks of this class nevertheless increased. Thus, by 1872 there were 60 noblemen with the right to vote in the Chisinau uyezd, and 52 more people in Orgey. There were 48 such persons in Soroca uyezd, and 35 in Iasi. ${ }^{27}$ In total, there were 95 persons in the mentioned districts. The growth dynamics of the upper class of Bessarabia can be judged by the digital indicators in Table 6.

Considering the data from Table 6, one can see that over 20 years the number of nobles in Bessarabia has grown by $13.9 \%$. It is also noteworthy that the majority of hereditary nobles were concentrated in the uyezds, while the personal nobles were mainly concentrated in the urban environment. It is also important that by 1890 the number of hereditary nobles slightly exceeded the number of personal nobles, and this situation remained until the early twentieth century. Actually, in 1897 there were 11,774 hereditary nobles in the province. The number of personal nobles was $10,090.28$ In general, the nobility of Bessarabia constituted an extremely motley group in ethnic terms (Table 7).

Mentioning the ethnic heterogeneity of the noble landowners of Bessarabia, we should also pay attention to their proprietary inequality. Thus, among the noble families included in the alphabetical list in 1821, 74 families owned inherited estates. The size of their land ownership varied from several hundred square fathoms to tens of thousands acres. Another 13 families owned the purchased estates. Fifteen nobles acquired real

\footnotetext{
${ }^{25}$ An alphabetical list of all the noble families of the Bessarabian region, approved in the nobility, the Heraldry, the Temporary Heraldry Presence and the Heraldry Department of the Governing Senate, with an indication of their names, since the existence of a noble deputy assembly in Bessarabia: that is, from 1824 to 1871. RSHA. F. 1343. L. 51. Vol. 614, sheets 177-188.

${ }^{26}$ Calculations based upon the list of persons who submitted a petition to the Bessarabian Noble Assembly between 1821 and 1854: RSHA. F. 1343. L. 51. Vol. 614, sheets 219-238.

27 M.A.Kantakuzin to N.I.Shebeko January 27, 1872. RSHA. F. 1284. L. 91-A. Vol. 89, sheet 8.

28 The first census of the Russian Empire in 1897. Vol. 3. 1905, p. 21.
} 
estate from their wives' dowry and 11 families were landless. ${ }^{29}$ At the same time, most of the families awaiting approval or not recognized in the nobility in the second quarter of the nineteenth century were owners of small estates or landless. Over time, the group of low-income noblemen was replenished by those persons who were previously listed as middleclass landowners or even very rich landowners. So, the heirs of Nikolai Ivanovich Khinkul were the owners of 2160 acres of land in the village of Sekhereny. However, in the early 1820 s a litigation with Major General Y.Y. Cheremisinov began over this site, which lasted more than 30 years. The general himself did not live to see the final court decision. Regardless of the outcome of the trial, the Khinkuls were never able to become any wealthy landowners. Long-term property disputes led to the degradation of farms, in which the disputing parties did not invest sufficient funds for their development. By the end of the 1860s, in the Orgeyev district there were only four representatives of the numerous noble family of the Khinkuls, all of whom were patrimonial owners of small estates. In particular, Georgy Khinkul had 194 acres of land, Alexander Khinkul had 57 acres, Mikhail Khinkul had 73 acres, Peter Khinkul had 43 acres. ${ }^{30}$

In general, the middle of the nineteenth century turned out to be not the happiest time for the landlord estates. It is obvious that the noble estates at that time were upset by frequent crop failures, the appearance of a huge mass of locusts and a lack of current assets. The funds obtained from economic activities were often sufficient only to meet their own needs in these years. It turned out to be extremely difficult to obtain the necessary financial resources for the development of agricultural technology. There was also a general drop in the number of private estates in the region. In 1854 there were 1221 private estates in Bessarabia ${ }^{31}$, whereas in 1864 their number was reduced to 1121 estates. ${ }^{32}$ This number included monastic estates as well. According to A. Zashchuk, in 1857 private individuals and families owned a little more than 900 estates, of which a little more than 500 were owned by the nobles. ${ }^{33}$ If we divide the noble landowners by districts, then there were 123 such persons in the Khotin uyezd, 59 in Soroca, 102 in Orgeyev, 91 in Iasi, 78 in Chisinau, 23 in Bendery, and 32 in Akkerman. ${ }^{34}$

The given figures can be correlated with the number of the nobles of Bessarabia, who were registered by 10 revisions. In total, according to

\footnotetext{
${ }^{29}$ Calculations based upon the "Noble genealogy book, divided into parts". RSHA. F. 1151. L. 3 (1844). Vol. 219-251.

30 The list drawn up by the Orgeyev Provisional Commission on the basis of paragraph 2, Art. 23 of the Provisions of land institutions for those having the right to participate in the electoral congress of uyezd landowners through authorized attorneys. RSHA. F. 1284. L. 92 (1869). Vol. 24, sheet 43.

${ }^{31}$ Report of the Bessarabian Governor of 1854. RSHA. F. 1281. L. 6 (1855). Vol. 76, sheet 7.

32 Report of the Bessarabian Governor of 1864. Ibid. Vol. 11, sheet 16.

${ }^{33}$ Zashchuk A 1862, 219.

${ }^{34}$ Ibid, 220.
} 
the statistical committee, there were 2820 hereditary nobles (1440 men and 1380 women) living in the province with the exception of Khotin uyezd. ${ }^{35}$ Unfortunately, the specified certificate did not contain information on the Khotin uyezd. However, the missing part of the upper class of this part of the province can be roughly determined from other sources. In particular, according to the information of the local governor (see table 4), it follows that in 1858 there were 3396 hereditary noblemen living in the province, therefore, there were about 570 persons of this rank in the Khotin uyezd. The nobles were distributed by districts as follows: 449 male and 407 female lived in Chisinau, 65 male and 63 female lived in Akkerman, 27 male and 34 female in Bendery, 236 male and 259 female in Iasi, 408 male and 378 female in Orgeyev, 255 male and 239 female in Soroca. ${ }^{36}$ Obviously, when comparing these indicators with the number of noble estates, it turns out that not all nobles had estates in the region. According to the information of the regional statistical committee, there were 750 landed estates in Bessarabia in 1863, of which 581 estates were in personal possession $(3,618,273$ acres of land). Another 169 estates were jointly owned $\left(1,110,429\right.$ acres of land). ${ }^{37}$ Obviously, part of the nonnobility class was included in the number of owners of 750 estates, since the figures are somewhat exaggerated.

In 1869 the total number of estates increased in comparison with 1863, reaching 1129 . Of these, only 672 belonged to the upper class, while there were about 4000 hereditary nobles in the region. ${ }^{38}$ Note that the number of owners and the number of places were not equal. Large landowners owned several estates, either in one district or in different parts of Bessarabia. Thus, the number of landless nobles continued to make up a significant part of the local social elite. Obviously, the highest estate of Bessarabia was quickly replenished with landless nobles from among the persons newly arrived in the region, mainly on duty. Of course, not all officials linked their lives with Bessarabia. The overwhelming majority of the nobles lived in the region for a short time, then continuing to serve in other provinces of the empire. Over the entire period of Bessarabia's existence as part of Russia, several tens of thousands of nobles served in it, and, obviously, a tenth of them remained for permanent residence.

Considering the state of noble land tenure, we note that in the nineteenth - early twentieth centuries, the estates of the Bessarabian nobility were at great risk of ruin due to the scarcity of financial resources. The absence of serfdom in the region, and hence of free labor, forced the landowners to hire workers, which required seeking working capital. Of course, there were various ways of forcing the Tsaran to work on the lands

\footnotetext{
35 Notes of the Bessarabian Regional Statistical Committee. Chisinau, 1864.Vol. 1.P. 17.

36 Ibid.

37 Ibid, 7.

${ }^{38}$ Report of the Bessarabian Governor of 1869. RSHA. F. 1281. L. 7 (1879). Vol. 72 , sheet 6.
} 
of the landowners. However, they were not unlimited, therefore, the need for hired workers continued. Another factor that weakened the position of the Bessarabian landowners was the absence of credit institutions in the region for a long time. This circumstance contributed to the strengthening of the role of usurers and complicated the financial situation of the landed nobility. Of the 1221 estates mentioned above, 41 properties were mortgaged from various creditors in 1854. Of these, 19 were put in a distress for non-payment of interest and were waiting for the sale, and 15 were sold at auction for the inability of the owners to repay the loan. ${ }^{39}$ In 1864, 50 estates were mortgaged and re-mortgaged, of which 13 were put in a distress and 4 were sold at auction. 40 Obviously, such a number of bankrupt debtors for certain years makes up a small part of all noble owners. However, in the future, their total mass grew. At the same time, this process still threatened the general position of the regional elite. The tendency alarmed the local noble circles, forcing them to ask for the organization of credit institutions in the region.

In subsequent years, yet one threat for the noble land tenure arose. It came from the planned for the end of the 1860s peasant reform. Even the tsarist authorities noted that the landowners of Bessarabia suffered more significant losses during the redemption of land than the landowners of other provinces. ${ }^{41}$ In fact, in the region, the villagers received a significant area of common land for insignificant, in comparison with the rent, remuneration for the landlords. In Bessarabia, it was extremely difficult to find even a few estates in which the villagers would refuse the full size of the allotment land. There were many cases when the poor received a quarter of a certain amount as a gift. However, during the implementation of such transactions, and the provincial authorities knew about this, the land owners were forced to pay the peasants 30 or more rubles for each tithe that the villagers refused. ${ }^{42}$ In general, the landowners of the region were to lose more than 420,000 acres of quality land that was allocated to the settlers.

The land losses listed above are typical for the majority of large estates in Bessarabia, as well as for average owners. Thus, the pre-reform position of the local nobility was more stable. For example, the scale of land ownership of the nobles in Orgeyev uyezd on the eve of the peasant reform can be judged by the following data: 117 people possessed estates in this part of Bessarabia, of whom 98 were nobles $(78$ men and 20 women). Each of this part of the district patrimonials had more than 500 acres. The remaining 19 nobles possessed less than 500 acres of land, or owned a household in the city of Orgeyev. In terms of these indicators, Orgeyev uyezd was second only to Khotin and Soroka uyezds, where there

\footnotetext{
${ }^{39}$ Report of the Bessarabian Governor of 1854. RSHA. F. 1281. L. 6 (1855). Vol. 76, sheet 7.

40 Report of the Bessarabian Governor of 1864. Ibid. L. 7 (1865). Vol. 11, sheet 16.

${ }^{41}$ Common case of the Bessarabian province. RSHA. F. 577. L. 50. Vol. 116, sheet 20.

42 Ibid.
} 
were 184 and 113 owners of estates and households, respectively. Note that the number of large owners was relatively small everywhere. Among them Orgeyev uyezd had 33 owners, whose estates ranged from 2700 to 19192 acres. Of these, the smallest land area was owned by Maria Protopopova and Ivan Russo (2700 acres each), and the largest was Stepan Glavche (19192 acres). Another 17 nobles had between 2701 and 5399 acres of land. Nine estates covered the area from 5400 to 8100 acres, two had up to 10800 acres, two had more than 10800 acres, one had more than 13500 acres. ${ }^{43}$ Among the average local nobles in the Orgeyev district, 38 owners had estates that ranged from 540 to 1440 acres of land. Of these, 11 people owned estates of 540 acres, 11 more nobles had between 1080 and 1350 acres. One landowner, namely K.M. Kotrutsa, possessed a little less than 1365 acres of land in the villages of Gertop Mare and Odaya Kotrucesti. His wife, Maria Onisimovna, owned an estate in the village of Rospopeni in Orgeyev uyezd with an area of 1755 acres.

From the above, it is clear that land holdings in Bessarabia were in active movement. In the last decades of the nineteenth century the process of redistribution of land ownership has even intensified to a certain extent. The largest amount of land continued to be concentrated in the hands of the nobles of the northern uyezds, Balti, Soroca and Khotin. According to the information of the Bessarabian noble deputy assembly in 1889, the nobles owned 2,359,044 acres of land: 529,200 acres in Balti uyezd, 375,300 acres in Soroca uyezd, 334,800 acres in Chisinau uyezd, 329,400 acres in Khotin uyezd, 310,500 acres in Bendery uyezd, 253,800 acres in Orgeyev uyezd and 218,700 acres in Akkerman uyezd. All this land was estimated by the tax authorities at 18 million rubles. The nobles also owned property in towns for another 728 thousand rubles. ${ }^{44}$

These indicators were formed as a result of the peasant reform, which led in the 1870s-1880s to the seizure of significant areas of land from landlords. Thus, in 1874-1897, the noble land ownership in Bessarabia decreased by 324937 acres. Below we provide information on the movement of noble land tenure in the 23 years. True, they differ somewhat from the above figures. From these data it is clear that only in Chisinau uyezd the nobles were able to increase their holdings. The others had losses (Table 8).

The tendency to reduce land ownership among the nobles is clearly characterized by the average indicators of such holdings. Thus, in 1877 the average area of a private landowner was 1197 acres, whereas in 1905 it decreased to 812 acres. ${ }^{45}$ In part, the size of the noble holdings can be judged by the mortgaged estates in the State Noble Land Bank. For example, in the period between July 7, 1886 and June 26, 1893, as many

\footnotetext{
43 On the opening of zemstvo institutions in the Bessarabian region. RSHA. F. 1284. L. 92 (1869). Vol.. 24. Sheets, 27, 30-31.

44 Odessa Bulletin. January 15, 1890 No. 13.

45 Land tenure statistics, 1906, 46.
} 
as 286 estates were mortgaged: 50 in Khotin uyezd, 68 in Balti, 52 in Soroca, 58 in Orgeyev, 47 in Chisinau, 4 in Bendery and Akkerman uyezds and 3 in Izmail uyezd. ${ }^{46}$ In Khotin uyezd, the area of the mortgaged estates ranged from 216 to 11119 acres of good land. Among them there were only 4 estates with an area of 216 to 270 acres; 16 of 270 to 1350 acres; 15 of 1350 to 2700 acres; 13 of 2700 to 5400 acres; 2 of over 5400 acres. The situation with land borrowers was somewhat different in Orgeyev uyezd. There were 58 estates with an area ranging from 25 up to 7476 acres, of which 5 estates were smaller than 135 acres, 1 one with an area of 178 acres, 31 estates covered an area between 270 and 1350 acres of good land, 14 estates were between 1350 and 2700 acres, 5 estates had between 2700 and 5400 acres, and 2 estates were over 5400 acres. ${ }^{47}$ The above indicators clearly characterize the existing system of noble land tenure, which differed by district. While there were relatively many medium and large estates in Khotin uyezd, small and medium-sized owners prevailed in Orgeyev uyezd.

Due to the loans from state and private banks, the nobles of Bessarabia lost a significant part of their possessions. According to Y.S. Grosul and I.G. Budak, only by 1885 Bessarabian nobles mortgaged 99,172 acres of land in the Noble Bank. Another 308,370 acres were mortgaged in the Bessarab-Tavria land bank, 1,401,937 acres in the Zemstvo bank of the Kherson province, 20,207 acres in the Mutual Land Credit Society. In total, $1,820,713$ out of $3,507,416$ acres, or $51.9 \%$ of all private land were mortgaged in banks. 48 Over the years, the number of mortgaged estates only grew. So, by January 1, 1906, 551 noble estates with a total area of 1,185,295 acres were pledged in the Noble Bank. ${ }^{49}$ Many of the borrowers were unable to repay the loans and were forced to part with their possessions. Of the 551 estates noted in 1905, 97 estates were lost. In the late nineteenth - early twentieth centuries, the process of transferring land ownership from the hands of the nobility to the hands of representatives of other classes became commonplace.

The above examples vividly depict the complicated fate of noble land tenure. A significant part of the landowners of Bessarabia entered the twentieth century with extremely burdensome economic problems, among which the most intractable were debt obligations to various creditors. It should be noted that the reason for the instability of noble land tenure, in addition to the natural fragmentation of estates during the transfer of individual plots to the heirs, was the weak business abilities of landowners. It was because of the poor organization of economic activities

\footnotetext{
${ }^{46}$ List of special assessments made by the Bessarabian branch of the State Noble Land Bank between July 7, 1886 and June 26, 1893. RSHA. F. 593. L. 1. Vol. 172, sheets 93-100.

47 Author's calculations.

48 Grosul, Y.S., Budak 1972, 154.

49 Report of the Special Department of the State Noble Land Bank of 1905, Saint Petersburg, 1906, pp. 10-11.
} 
that the nobles lost the bulk of their possessions. Examining the economic documents of that time, we are convinced that during the 100-year period of Bessarabia's stay in the Russian Empire, only in a few of the noble estates the methods of economic management changed. Objectively, the local nobility of this province was going through an economic crisis that was characteristic of the entire noble economy of Russia in the late nineteenth through early twentieth centuries. 
Table 1

Population of Bessarabian region in 1828 , including nobles

\begin{tabular}{|c|c|c|c|c|c|c|c|c|c|c|}
\hline \multirow[t]{2}{*}{ Uyezd } & \multicolumn{4}{|c|}{ Population } & \multicolumn{3}{|c|}{ Number of nobles } & \multirow{2}{*}{$\begin{array}{l}\text { Total } \\
\text { nobles }\end{array}$} & \multirow{2}{*}{$\begin{array}{l}\% \\
\text { total } \\
\text { nobles }\end{array}$} & \multirow{2}{*}{$\begin{array}{l}\text { \% total } \\
\text { popula } \\
\text { tion }\end{array}$} \\
\hline & Male & Female & Total & $\%$ & $\begin{array}{l}\frac{0}{\pi} \\
\frac{\pi}{0} \\
0 \\
0\end{array}$ & 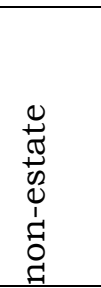 & 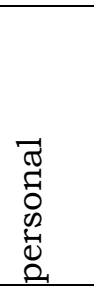 & & & \\
\hline Khotin & 61955 & 55539 & 117534 & 29,3 & 38 & 11 & 5 & 54 & 7,6 & 0,1 \\
\hline Iasi & 52630 & 49387 & 102017 & 25,4 & 61 & 35 & 215 & 311 & 43,7 & 0,3 \\
\hline Orgeyev & 61332 & 52822 & 114154 & 28,4 & 94 & 95 & 110 & 299 & 42,0 & 0,3 \\
\hline Bender & 21399 & 17942 & 39341 & 9,8 & 4 & 7 & 19 & 30 & 4,2 & 0,1 \\
\hline Akkerman & 10970 & 9567 & 20537 & 5,1 & - & 5 & 4 & 9 & 1,3 & 0,04 \\
\hline Izmail & 4217 & 3917 & 8134 & 2,0 & 3 & - & 6 & 9 & 1,3 & 0,1 \\
\hline Total & 212543 & 189174 & 401717 & 100 & 200 & 153 & 359 & 712 & 100 & 0,2 \\
\hline$\% \%$ & 52,9 & 47,1 & 100 & - & 28,1 & 21,5 & 50,4 & 100 & - & - \\
\hline
\end{tabular}

Source: Information from the files of the National Archives of the Republic of Moldova (hereinafter NARM). F. 2. L. 1. Vol. 3643, 4476A. 
Table 2

Number of nobles who had the right to participate in the noble elections in 1835

\begin{tabular}{|c|c|c|c|c|c|c|c|}
\hline Uyezd & $\begin{array}{l}\text { Nobles who } \\
\text { had the right } \\
\text { to directly } \\
\text { participate in } \\
\text { elections due } \\
\text { to land } \\
\text { ownership }\end{array}$ & $\begin{array}{l}\text { Nobles who } \\
\text { took part in } \\
\text { the elections } \\
\text { as attorney }\end{array}$ & $\begin{array}{l}\text { Noblewomen } \\
\text { who could } \\
\text { take part in } \\
\text { elections } \\
\text { through } \\
\text { trustes }\end{array}$ & $\begin{array}{l}\text { Nobles } \\
\text { without the } \\
\text { right to } \\
\text { participate in } \\
\text { elections, but } \\
\text { approved to } \\
\text { nobility by the } \\
\text { Senate }\end{array}$ & $\begin{array}{l}\text { Nobles } \\
\text { recognized } \\
\text { by the } \\
\text { Assembly, } \\
\text { but not } \\
\text { approved } \\
\text { by the } \\
\text { Senate }\end{array}$ & Total & $\%$ \\
\hline Khotin & 27 & 16 & 6 & - & 232 & 303 & 43,0 \\
\hline Iasi & 38 & 20 & 8 & 1 & 119 & 186 & 26,4 \\
\hline Orgeyev & 49 & 16 & 6 & - & 232 & 303 & 43,0 \\
\hline Bender & 1 & 3 & - & - & 22 & 26 & 3,7 \\
\hline Akkerman & 2 & 1 & - & - & 5 & 8 & 1,1 \\
\hline Izmail & 9 & 6 & 8 & - & 17 & 40 & 5,8 \\
\hline Total & 126 & 60 & 24 & 1 & 493 & 704 & 100 \\
\hline$\% \%$ & 17,9 & 8,5 & 3,5 & 0,1 & 70 & 100 & - \\
\hline
\end{tabular}

Source: Ghtrasim C. Evoluția nobilimii din Basarabia sub dominanție țaristă statutul social-economic și mentalități collective (1812-1873). Teză de doctor în istorie. Chișinău, 2018. P. 187. 
Table 3

The number of hereditary and personal nobles of the Bessarabian province in 1848

\begin{tabular}{|c|c|c|c|c|c|c|c|c|c|c|c|}
\hline Uyezd & \multicolumn{9}{|c|}{ Hereditary } & \multicolumn{2}{|l|}{ Personal } \\
\hline & \multicolumn{2}{|c|}{$\begin{array}{l}\text { Included in the } \\
\text { genealogy book of } \\
\text { Bessarabia }\end{array}$} & \multicolumn{2}{|c|}{$\begin{array}{l}\text { Included in the } \\
\text { genealogy books of } \\
\text { other provinces }\end{array}$} & \multicolumn{2}{|c|}{$\begin{array}{l}\text { Not included in } \\
\text { genealogy books }\end{array}$} & \multicolumn{3}{|c|}{ Total } & \multirow[t]{2}{*}{ Serving } & \multirow[t]{2}{*}{$\begin{array}{l}\text { Non- } \\
\text { serving }\end{array}$} \\
\hline & $\begin{array}{l}\text { Family } \\
\text { heads } \\
\text { and } \\
\text { singles }\end{array}$ & $\begin{array}{l}\text { Male } \\
\text { children } \\
\text { in } \\
\text { families }\end{array}$ & $\begin{array}{l}\text { Family } \\
\text { heads } \\
\text { and } \\
\text { singles }\end{array}$ & $\begin{array}{l}\text { Male } \\
\text { children } \\
\text { in families }\end{array}$ & $\begin{array}{l}\text { Family } \\
\text { heads } \\
\text { and } \\
\text { singles }\end{array}$ & $\begin{array}{l}\text { Children } \\
\text { in } \\
\text { families }\end{array}$ & $\begin{array}{l}\text { Included } \\
\text { in the } \\
\text { genealogy } \\
\text { book of } \\
\text { Bessarabi } \\
\text { a }\end{array}$ & $\begin{array}{l}\text { Include } \\
\mathrm{d} \text { in the } \\
\text { genealo } \\
\text { gy } \\
\text { books } \\
\text { of other } \\
\text { provinc } \\
\text { es }\end{array}$ & $\begin{array}{c}\text { Not } \\
\text { included } \\
\text { in } \\
\text { genealog } \\
\text { y books }\end{array}$ & & \\
\hline Chisinau & 120 & 39 & 49 & 9 & 100 & 56 & 159 & 58 & 156 & 280 & 100 \\
\hline Orgeyev & 153 & $\begin{array}{c}44 \& \\
109 \text { not } \\
\text { included } \\
\text { in the } \\
\text { book }\end{array}$ & 56 & $\begin{array}{c}4 \& 64 \\
\text { not } \\
\text { included } \\
\text { in the } \\
\text { books }\end{array}$ & 45 & 50 & $\begin{array}{c}197 \& 109 \\
\text { not } \\
\text { included } \\
\text { in the } \\
\text { book }\end{array}$ & $\begin{array}{c}60 \& \\
\text { not } \\
\text { include } \\
\text { d in the } \\
\text { books }\end{array}$ & 95 & 14 & 60 \\
\hline Iasi & 66 & $\begin{array}{c}15 \& 32 \\
\text { not } \\
\text { included } \\
\text { in the } \\
\text { book }\end{array}$ & 29 & $\begin{array}{c}19 \& 28 \\
\text { not } \\
\text { included } \\
\text { in the } \\
\text { books }\end{array}$ & 25 & 24 & $\begin{array}{c}81 \& 32 \\
\text { not } \\
\text { included } \\
\text { in the } \\
\text { book }\end{array}$ & $\begin{array}{c}48 \& 28 \\
\text { not } \\
\text { include } \\
\text { d in the } \\
\text { books }\end{array}$ & 49 & 34 & 43 \\
\hline Soroca & 87 & $\begin{array}{l}21 \& 37 \\
\text { not } \\
\text { included } \\
\text { in the } \\
\text { book }\end{array}$ & 31 & $\begin{array}{c}25 \& 44 \\
\text { not } \\
\text { included } \\
\text { in the } \\
\text { books }\end{array}$ & 46 & 37 & $\begin{array}{c}108 \& 37 \\
\text { not } \\
\text { included } \\
\text { in the } \\
\text { book }\end{array}$ & $\begin{array}{c}56 \& 44 \\
\text { not } \\
\text { include } \\
\text { d in the } \\
\text { book }\end{array}$ & 83 & 93 & 36 \\
\hline
\end{tabular}




\begin{tabular}{|c|c|c|c|c|c|c|c|c|c|c|c|}
\hline Khotin & 63 & $\begin{array}{c}24 \& 31 \\
\text { not } \\
\text { included } \\
\text { in the } \\
\text { book }\end{array}$ & 106 & $\begin{array}{c}14 \& 72 \\
\text { not } \\
\text { included } \\
\text { in the } \\
\text { books }\end{array}$ & 82 & 25 & $\begin{array}{c}87 \& 37 \\
\text { not } \\
\text { included } \\
\text { in the } \\
\text { book }\end{array}$ & $\begin{array}{c}120 \& \\
72 \text { not } \\
\text { include } \\
\text { d in the } \\
\text { books }\end{array}$ & 107 & 39 & 27 \\
\hline Bender & 6 & $\begin{array}{l}4 \text { not } \\
\text { included } \\
\text { in the } \\
\text { book }\end{array}$ & 11 & $\begin{array}{l}5 \text { not } \\
\text { included } \\
\text { in the } \\
\text { books }\end{array}$ & 21 & 8 & $\begin{array}{c}87 \& 37 \\
\text { not } \\
\text { included } \\
\text { in the } \\
\text { book }\end{array}$ & $\begin{array}{c}11 \& 5 \\
\text { not } \\
\text { include } \\
\text { d in the } \\
\text { books }\end{array}$ & 29 & 17 & 18 \\
\hline Cahul & 6 & $\begin{array}{c}2 \& 6 \\
\text { not } \\
\text { included } \\
\text { in the } \\
\text { book }\end{array}$ & 35 & $\begin{array}{c}30 \text { not } \\
\text { included } \\
\text { in the } \\
\text { books }\end{array}$ & 47 & 25 & $\begin{array}{c}8 \& 6 \text { not } \\
\text { included } \\
\text { in the } \\
\text { book }\end{array}$ & $\begin{array}{c}35 \& 30 \\
\text { not } \\
\text { include } \\
\text { d in the } \\
\text { books }\end{array}$ & 72 & 63 & 38 \\
\hline Akkerman & 12 & $\begin{array}{c}14 \text { not } \\
\text { included } \\
\text { in the } \\
\text { book }\end{array}$ & 44 & $\begin{array}{c}6 \& 37 \\
\text { not } \\
\text { included } \\
\text { in the } \\
\text { books }\end{array}$ & 38 & 24 & $\begin{array}{c}12 \& 14 \\
\text { not } \\
\text { included } \\
\text { in the } \\
\text { book }\end{array}$ & $\begin{array}{c}50 \& 37 \\
\text { not } \\
\text { include } \\
\text { d in the } \\
\text { books }\end{array}$ & 62 & 89 & 40 \\
\hline $\begin{array}{l}\text { Total in the } \\
\text { province }\end{array}$ & 513 & $\begin{array}{c}145 \& \\
233 \text { not } \\
\text { included } \\
\text { in the } \\
\text { book }\end{array}$ & 361 & $\begin{array}{c}77 \& 280 \\
\text { not } \\
\text { included } \\
\text { in the } \\
\text { books }\end{array}$ & 404 & 249 & $\begin{array}{c}658 \& 233 \\
\text { not } \\
\text { included } \\
\text { in the } \\
\text { book }\end{array}$ & $\begin{array}{c}438 \& \\
280 \text { not } \\
\text { include } \\
\text { d in the } \\
\text { books }\end{array}$ & 653 & 622 & 362 \\
\hline
\end{tabular}

Source: Correspondence of the Noble Assembly with the Bessarabian governor. NARM. F. 88. L. 1. Vo1. 1262, sheets $258-259$. 
Table 4

Number of nobles in 1842 - 1861

\begin{tabular}{|l|c|c|c|c|c|c|}
\hline \multirow{2}{*}{ Year } & \multicolumn{3}{|c|}{ Noble categories } & \multicolumn{2}{c|}{$\% \%$} \\
\cline { 2 - 7 } & Appointed & Including voters & Personal & Total & Appointed & Personal \\
\hline 1842 & 948 & ca. 200 & 2530 & 3478 & 27,3 & 72,7 \\
\hline 1843 & 821 & ca. 200 & 2146 & 2967 & 27,7 & 72,3 \\
\hline 1844 & 1636 & ca. 200 & 3675 & 5311 & 30,8 & 69,2 \\
\hline 1845 & 4323 & ca. 200 & 1669 & 5992 & 72,1 & 27,9 \\
\hline 1846 & 4239 & ca. 200 & 1838 & 6077 & 69,8 & 30,2 \\
\hline 1847 & 2416 & ca. 200 & 2576 & 4991 & 48,4 & 51,6 \\
\hline 1848 & 2552 & 209 & 2974 & 5496 & 45,9 & 54,1 \\
\hline 1849 & 2691 & 209 & 3050 & 5741 & 46,9 & 53,1 \\
\hline 1850 & 2699 & 209 & 2718 & 5417 & 49,17 & 54,17 \\
\hline 1851 & 3015 & 209 & 2841 & 5856 & 51,5 & 48,5 \\
\hline 1852 & 3157 & 209 & 3718 & 6875 & 53,7 & 46,3 \\
\hline 1853 & 3122 & n/a & 2854 & 5976 & 52,2 & 47,8 \\
\hline 1854 & 3376 & 131 & 2849 & 6225 & 54,2 & 45,8 \\
\hline 1855 & 2501 & 131 & 2780 & 5281 & 47,4 & 52,7 \\
\hline 1856 & 3015 & 131 & 2984 & 5999 & 50,3 & 49,7 \\
\hline 1857 & 3522 & 235 & 3107 & 6629 & 53,1 & 46,9 \\
\hline 1858 & 3396 & 235 & 3952 & 7348 & 46,2 & 53,8 \\
\hline 1859 & 3810 & n/a & 4391 & 8201 & 46,5 & 53,5 \\
\hline 1861 & 3796 & n/a & 5287 & 9083 & 41,8 & 58,2 \\
\hline
\end{tabular}

Source: RSHA. F. 1263. L. 1. Vol. 1708, sheets 1124-1124 rev.; Vol. 1858, sheets 1000-1000 rev.; Vol. 2017, sheets 480-481; Vol. 2185, sheet 690; L. 2. Vol. 71, sheets 94-95; Vol. 86, sheets 95-95 rev.; Vol. 78, sheets 98-99; L. 3. Vol. 72, sheets 99-100; Vol. 76, sheets 102-103; Vol. 78, sheets 126-127; Vol. 91, sheets 110; Vol. 107, sheets 125-126; F. 1281. L. 5. Vol. 54, sheet 105; Vol. 58, sheet 46; Vol. 78, sheet 98; Vol. 86, sheet 95; Vol. 87, sheet 98; L. 6. Vol. 76, sheet 102. 
Table 5

Hereditary nobility of the Bessarabian region in 1861

\begin{tabular}{|c|c|c|c|c|c|c|c|c|}
\hline \multirow[t]{4}{*}{ City or uyezd } & \multicolumn{8}{|c|}{ потомственных дворян } \\
\hline & \multirow{2}{*}{\multicolumn{2}{|c|}{ Total }} & \multicolumn{4}{|c|}{ в том числе с правом голоса } & \multirow{2}{*}{\multicolumn{2}{|c|}{ без права голоса }} \\
\hline & & & \multicolumn{2}{|c|}{ во всех постановцениях } & \multicolumn{2}{|c|}{ в выборах } & & \\
\hline & Male & Female & Male & Female & Male & Female & Male & Female \\
\hline Khotin & 23 & 15 & 16 & 8 & 7 & 3 & 7 & 7 \\
\hline Khotin uyezd & 278 & 115 & 39 & 15 & 18 & 9 & 239 & 100 \\
\hline Balts & 25 & 17 & 8 & 6 & 6 & 3 & 17 & 11 \\
\hline Iasi uyezd & 413 & 140 & 42 & 14 & 25 & 6 & 371 & 126 \\
\hline Soroca & 12 & 5 & 6 & 3 & 4 & 1 & 6 & 2 \\
\hline Soroca uyezd & 66 & 9 & 36 & 2 & 26 & 8 & 30 & 7 \\
\hline Orgeyev & 17 & 10 & 7 & 3 & 6 & 4 & 10 & 7 \\
\hline Orgeyev uyezd & 604 & 174 & 69 & 10 & 35 & 10 & 535 & 104 \\
\hline Chisinau & 60 & 15 & 12 & 6 & 11 & 7 & 48 & 9 \\
\hline Chisinau uyezd & 79 & 46 & 38 & 9 & 33 & 11 & 41 & 37 \\
\hline Bender & 9 & 3 & 1 & - & 1 & - & 8 & 3 \\
\hline Bender uyezd & 40 & 9 & 6 & - & 5 & - & 34 & 9 \\
\hline Akkerman & 10 & 3 & 2 & - & 1 & 1 & 8 & 3 \\
\hline Akkerman uyezd & 25 & 8 & 3 & - & 3 & - & 22 & 8 \\
\hline \multirow[t]{2}{*}{ Total } & 1661 & 569 & 285 & 76 & 181 & 63 & 1376 & 493 \\
\hline & \multicolumn{2}{|c|}{2230} & \multicolumn{2}{|c|}{361} & \multicolumn{2}{|c|}{244} & \multicolumn{2}{|c|}{1869} \\
\hline
\end{tabular}

Source: Notes of the Bessarabian Regional Statistical Committee. Chisinau, 1864.Vol. 1. P. 31. 
Table 6

The number of hereditary and personal nobles in the Bessarabian province in 1870, 1880, and 1890

\begin{tabular}{|l|c|c|c|c|c|c|c|c|c|}
\hline \multirow{2}{*}{ Uyezd } & \multicolumn{3}{|c|}{1870} & \multicolumn{3}{|c|}{1880} & \multicolumn{3}{c|}{1890} \\
\cline { 2 - 11 } & hereditary & personal & total & hereditary & personal & total & hereditary & personal & Total \\
\hline In towns & 1339 & 3532 & 4871 & 1543 & 4060 & 5603 & 1644 & 3292 & 4936 \\
\hline Chisinau & 338 & 263 & 601 & 550 & 167 & 717 & 527 & 151 & 678 \\
\hline Orgeyev & 882 & 445 & 1327 & 814 & 576 & 1390 & 1071 & 256 & 1327 \\
\hline Balts & 365 & 216 & 581 & 451 & 148 & 599 & 550 & 153 & 703 \\
\hline Soroca & 487 & 460 & 947 & 497 & 266 & 763 & 516 & 263 & 779 \\
\hline Khotin & 746 & 175 & 921 & 571 & 307 & 878 & 833 & 852 & 1685 \\
\hline Bender & 36 & 65 & 101 & 120 & 47 & 167 & 154 & 47 & 201 \\
\hline Akkerman & 127 & 234 & 361 & 67 & 200 & 267 & 128 & 163 & 291 \\
\hline Izmail & - & - & - & 62 & 58 & 120 & 138 & 54 & 192 \\
\hline $\begin{array}{l}\text { Total in } \\
\text { uyezds }\end{array}$ & 2981 & 1858 & 4839 & 3132 & 1768 & 4901 & 3917 & 1939 & 5856 \\
\hline Total & 4320 & 5390 & 9710 & 4675 & 5829 & 10504 & 5561 & 5231 & 10792 \\
\hline
\end{tabular}

Source: Grosul, Y.S., Budak, I.G. Essays on the history of the national economy of Bessarabia (1861-1905). Chisinau, 1972 , p. 54. 
Table 7 Ethnic composition of the nobility of Bessarabia according to the First census of 1897

\begin{tabular}{|c|c|c|c|c|c|c|c|c|c|}
\hline \multirow[t]{3}{*}{ Languages or language groups } & \multirow{2}{*}{\multicolumn{3}{|c|}{ Hereditary nobles }} & \multicolumn{6}{|c|}{ Habitat } \\
\hline & & & & \multicolumn{3}{|c|}{ In towns } & \multicolumn{3}{|c|}{ In uyezds } \\
\hline & Male & Female & Total & Male & Female & Total & Male & Female & Total \\
\hline Russian & 3087 & 3496 & 6583 & 1883 & 2258 & 4141 & 1274 & 1238 & 2512 \\
\hline Ukrainian & 368 & 393 & 761 & 72 & 79 & 151 & 226 & 314 & 540 \\
\hline Belorussian & 15 & 15 & 30 & 7 & 6 & 13 & 8 & 9 & 17 \\
\hline Polish & 740 & 781 & 1521 & 414 & 449 & 863 & 326 & 332 & 658 \\
\hline Other Slavic languages & 12 & 24 & 36 & 9 & 16 & 25 & 3 & 8 & 11 \\
\hline Lithuanian-Latvian & 4 & 2 & 6 & 1 & - & 1 & 3 & 2 & 5 \\
\hline Romance, including Moldovan & 1261 & 1341 & 2602 & 112 & 141 & 253 & 1149 & 1200 & 2349 \\
\hline German and other Germanic languages & 48 & 70 & 118 & 34 & 40 & 74 & 14 & 30 & 44 \\
\hline Albanian & - & - & - & 8 & 17 & 25 & - & 1 & 1 \\
\hline Greek & 12 & 31 & 43 & - & - & - & 4 & 13 & 17 \\
\hline Armenian & 33 & 25 & 58 & 22 & 15 & 37 & 10 & 11 & 21 \\
\hline Gypsy & - & 1 & 1 & - & - & - & - & - & - \\
\hline Kartvelian & 4 & 1 & 5 & 4 & 1 & 5 & - & - & - \\
\hline Other Caucasian & 1 & - & 1 & 1 & 1 & 2 & - & - & - \\
\hline Finnish & 1 & 2 & 3 & 1 & 1 & 2 & - & 1 & 1 \\
\hline Turkish-Tatar & 2 & 1 & 3 & 1 & - & 1 & 2 & 2 & 4 \\
\hline Total & 5589 & 6185 & 11774 & 2570 & 3023 & 5593 & 3019 & 3162 & 6181 \\
\hline
\end{tabular}

Source: The first census of the Russian Empire in 1897. Vol. 3. Bessarabian province. Saint Petersburg, 1905 , pp. $226-242$. 
Table 8

The movement of noble land tenure in the uyezds of the Bessarabian province between 1874 and 1897

\begin{tabular}{|c|c|c|c|c|c|c|c|c|c|c|c|c|}
\hline \multirow[t]{2}{*}{ Uyezd } & \multicolumn{9}{|c|}{ Years } & \multicolumn{3}{|c|}{$\begin{array}{c}\text { Increase or decrease of } \\
\text { tenure in dessiatins } \\
\text { ( } 1 \text { des. }=2,7 \text { acres })\end{array}$} \\
\hline & 1874 & 1877 & 1880 & 1883 & 1886 & 1889 & 1892 & 1895 & 1897 & Years & $\begin{array}{c}\text { Incre } \\
\text { ase }\end{array}$ & $\begin{array}{c}\text { Decreas } \\
\mathrm{e}\end{array}$ \\
\hline Akkerman & 124238 & 114335 & 116406 & 114334 & 100934 & 87958 & 81807 & 99361 & 85607 & 23 & - & 38631 \\
\hline Bender & 125480 & 116933 & 126791 & 112191 & 119978 & 115189 & 115223 & 107550 & 110270 & 23 & - & 15210 \\
\hline Chisinau & 135790 & 126353 & 126353 & 124922 & 125019 & 124798 & 124273 & 125590 & 137898 & 23 & 2108 & - \\
\hline Balts & 214609 & 217369 & 217369 & 210809 & 209466 & 193373 & 196198 & 199245 & 197034 & 23 & - & 17575 \\
\hline Soroca & 169122 & 141521 & 141521 & 141725 & 146063 & 139319 & 139650 & 124823 & 127999 & 23 & - & 41123 \\
\hline Khotin & 129613 & 124461 & 124461 & 110076 & 110794 & 116381 & 122038 & 124544 & 123663 & 23 & - & 5950 \\
\hline Total & 1006984 & 931876 & 943805 & 899808 & 906785 & 869446 & 873720 & 877366 & 886637 & 23 & - & 120347 \\
\hline
\end{tabular}

Source: Report of the State Noble Land Bank for 1896. Saint Petersburg, 1898, pp. 46 - 49.

Translated from Russian by Alexander M. Amatov 


\section{References}

Ghtrasim, C. 2018. Evoluția nobilimii din Basarabia sub dominanție țaristă statutul social-economic și mentalități collective (1812-1873). Teză de doctor în istorie. Chișinău.

Grosul, Ia. S., Budak. I.G. 1972. Ocherki istorii narodnogo khoziaistva Bessarabii (1861-1905 gg.) [Essays on the History of the National Economy of Bessarabia (1861-1905)] Kishinev: Kartia Moldoveniaske. (In Russian).

Zapiski Bessarabskogo oblastnogo Statisticheskago Komiteta [Notes of the Bessarabian Regional Statistical Committee]. 1864, Vol. I. Kishinev: Pechat. v Tip. Oblastnogo Pravleniia. (In Russian).

Zashchuk, A. 1862. Part I. Materialy dlia geografii i statistiki Rossii. Bessarabskaia oblast [Materials for geography and statistics of Russia. Bessarabia region]. St. Petersburg: Tip. E. Veimara. (In Russian).

Materialy dlia geografii i statistiki Rossii, sobrannye ofitserami Generalnogo shtaba. Riazanskaia guberniya [Materials for geography and statistics of Russia, collected by officers of the General Staff. Ryazan Province]. 1860. Sost. M. Baranovich. St. Petersburg: Tip. tovarishchestva "Obshchestvennaia polza". (In Russian).

Otchet Osobogo otdela Gosudarstvennogo dvorianskogo zemelnogo banka za 1896 god [Report of the Special Department of the State Noble Land Bank for 1896]. 1898. St. Petersburg. (In Russian).

Otchet Osobogo otdela Gosudarstvennogo Dvorianskogo zemelnogo banka za 1905 g. [Report of the Special Department of the State Noble Land Bank for 1905]. 1906. St. Petersburg. (In Russian).

Pervaia vseobshchaia perepis naseleniia Rossiiskoi Imperii 1897 g. I Bessarabskaia guberniia (pod redaktsiei N.A. Troinitskago) [The first General Population Census of the Russian Empire in 1897, I Bessarabia province (edited by N.A. Troitskiy)]. 1905. Vol. 2. St. Petersburg: Izd-vo. Tsentr. Stat. komitetom M-va vn. Del. (In Russian).

Rumyniia: Rasskazy o Bessarabii, Bukovine, Moldavii i Valakhii: $S$ ist. Ocherkami [Romania: Stories about Bessarabia, Bukovina, Moldavia and Wallachia : With historical essays.]. 1867 (obl. 1868). Odessa: tip. L. Nitche. (In Russian).

Statistika zemlevladenii 1905 g.: Bessarabskaia guberniya [Statistics of land ownership in 1905: Bessarabia province]. 1906. Vol. 10. St. Petersburg: Tip. $\mathrm{SPb}$. AO pech. i pischebum. dela v Rossii "Slovo". (In Russian).

Fedoseeva, R. V. 2014. Part 2. "Chislennost i struktura dvorianstva Srednego Povolzhia vo vtoroi polovine XIX veka [The number and structure of the nobility of the Middle Volga region in the second half of the XIX century]." Istoricheskie, filosofskie, politicheskie i Iuridicheskie nauki, kulturologiia $i$ iskusstvovedenie. Voprosy teorii i praktiki. 1: 197-201. (In Russian).

Shapovalov, V. A. 2014. Pomestnoe dvorianstvo Evropeiskoi Rossii v 50-90-e gg. XIX veka (po materialam tsentralno-chernozemnykh gubernii) [The local nobility of European Russia in the 50-90s of the XIX century (based on the materials of 
the Central Chernozem provinces)]. Belgorod: ID "Belgorod" NIU "BelGU». (In Russian).

\section{About the author} University.

V.V. Morozan, Doctor of Science in History, is Professor of the St. Petersburg State

Received June, 02, 2021

Translation received November 18, 2021

Accepted December 28, 2021

Published February 08, 2022 